\title{
R\&D expenditure and innovation in the EU and selected member states
}

\section{Radka MacGregor Pelikánováa iD}

\begin{abstract}
Sustainable development and competitiveness cannot be achieved in our highly competitive global society without innovations. Innovations are typically the result of a financially demanding research process generating intellectual property assets, namely patented inventions or ideas for the digital setting and protected by copyright or otherwise. The EU is aware of it and its current strategy, Europe 2020 , states that 3\% of GDP should be allocated to R\&D by 2020 at the latest and this should boost innovation levels and make the EU a top global economic leader. Undoubtedly, innovation is indispensable and needs to be financed. However, the relation of involved factors and the related dynamic are unclear and have not received sufficient scientific and academic attention. To make an initial step to address this vacuum, three research questions are addressed. Firstly, what fraction of GDP goes towards R\&D, expressed by GERD, and what is the GERD trend in the EU and selected EU member states? Secondly, how many European patent applications were filed and patents granted, what was the success rate and how has digitalization been progressing in the EU and selected EU member states and what are the trends? Thirdly, can the possibility of a relationship be implied? These three questions are answered based on multi-disciplinary research employing hard data sources, such as Eurostat and EPO databases, official and/or legislative documents, such as Europe 2020, academic literature along with direct observation, field search and the own experience of the author. Such a conglomerate of diversified and multi-disciplinary data is to be processed by a myriad of appropriately matching methods, both of a quantitative and qualitative nature, and dominated by the holistic Meta-Analysis. Indices and indicators, such as GERD, EPO statistics and DESI, are comparatively employed while observing their time evolution in the entire EU and selected EU members. Their selection is made by the motivation to be representative and to face the (alleged) cliché about EU member states labeled as "good" (DE, FR), "lazy" PIGS $(P T, I T, G R, S P)$, leaving (GB), particular Scandinavian (DK, FI, SW) and central (AT, $C Z, P L)$. This highly original study answers all three questions - (i) the 3\% threshold
\end{abstract}

1 Radka MacGregor Pelikánová, Ph.D., LL.M., MBA, Metropolitan University Prague, Dubečská 900/10, 10031 Prague 10, Czech Republic, e-mail: radkamacgregor@yahoo.com (ORCID ID 0000-0001-9628-7146).

Received 24 July 2018; Revised 17 September 2018, 22 September 2018; Accepted 30 September 2018 
is not met in the larger part of the EU, (ii) the number of patent applications and granted patents keep growing along with digitalization, and (iii) the possibility of a relationship between these factors and trends exists, but is not conclusive or dramatically strong. This generates a set of original suggestions, such as that the differences between EU member states regarding innovations do not vanish and that although the Europe 2020 3\% threshold is not met, the number of patented inventions and the practical digitalization can still grow across the EU. Further and deeper research is needed and should help the EU to change its approach to innovations and make it more effective and efficient.

Keywords: DESI, Europe 2020, GERD, innovation, intellectual property, R\&D, research and development.

\section{INTRODUCTION}

For more than two decades, the EU has been proclaiming its ambition to become the most competitive and innovation-oriented economy in the world (EC, 2010) and its recognition that intellectual property (IP) is indispensable for that. IP involves intangible assets typically benefiting by industrial property protection, such as patents for inventions, and by copyright protection, such as a copyright for a creative and materialized idea, including software. The current EU strategy, called Europe 2020, sets as one of its five targets a threshold of at least 3\% of the EU's gross domestic product (GDP) to be invested in research and experimental development (R\&D) in 2020. R\&D comprises creative work undertaken on a systematic basis in order to increase the stock of knowledge, including knowledge of man, culture and society and the use of this stock of knowledge to devise new applications (OECD, 2015). Europe 2020 states that the satisfaction of a 3\% threshold will inevitably lead to a boost in the competitiveness of the EU and EU businesses, especially the setting (EC, 2010) in line with the growth of corporate social responsibility (Pakšiová, 2016). The EU seems confident that the increase in spending on R\&D will generate a rise in innovations. However, neither the EU and its representatives nor academia have been able to analyze, verify and explain the $3 \%$ threshold and this co-relation and its components in depth. It appears that they simply observe the increase of competitiveness in economies where the $3 \%$ threshold is targeted (USA) or even surpassed (Japan).

Inventions are vital for competitiveness in the 21st century (Terzić, 2017). They are products of costly processes requiring education and knowledge efficiency (Polcyn, 2018) along with direct and indirect financing and can lead to innovation, but this line is far from straight forward. Since an innovation means developing a new idea and putting it into the business (Kalanje, 2018), spending more money on R\&D can, but not necessarily, lead to innovations. 
On the one hand, many research projects wind up as dead ends, despite the amount of money spent. On the other hand, some ideas come at basically no cost and can lead to wonderful innovations. Since the quantification of the threshold of $3 \%$ is a mere following of patterns in different societies, economies and culture, the Europe 2020 confidence seems surprising - how can the EU be sure that the 3\% threshold is going to be met in 2020 and that this will result in more innovations and increased competitiveness?

Hence, three critical and, so far, not fully answered research questions at the EU level and the EU member state's level emerge - (i) how much is spent on R\&D, (ii) how many patentable inventions are filed and succeed and how many other ideas lead to innovations, and (iii) can we imply a possible relationship and what are the trends? The general claims about difficulties to assess R\&D spending and its trends and about the intangible nature and quantification impossibilities of inventions (MacGregor Pelikánová, 2014), patentable or copyrightable, along with the misunderstanding of the casual nexus line spending-idea-innovation do not justify the omission of appropriate studies and publications. Their lack excludes a deeper understanding and negatively impacts further work towards making the EU setting for innovation more effective and efficient. This vacuum is to be addressed while appreciating the dynamic interaction between spending and innovation at both the EU level and selected EU member state's level within the time period of Europe 2020. The stable and uncontestable starting premises are that Europe 2020 demands $3 \%$ of GDP to be spent on R\&D by 2020 , that ideas produced by R\&D can be predominantly patentable inventions or ideas usable in the digital environment (Polanski, 2015), and that there is a certain link between R\&D and innovation.

The aim of this paper and the rationale for the study are bound to three research questions with respect to Europe 2020, namely the EU and selected EU member states. Firstly, what fraction of GDP is allocated to R\&D and what is the trend? Secondly, how many applications were filed for patents on inventions, how many patents were granted, what was the success rate, how has digitalization progressed, and what are the trends? Thirdly, can we imply the possibility of a relationship and what are the trends? All three research questions deal with under-researched and not deeply analyzed issues and aspects which often, due to their intangibility, complexity and impossibility of straight quantitative measuring, are avoided and/or simplified. The EU believes in an automatic increase in innovation due to an increase in spending without offering any hard data, or at least critical elaborated analyses, to back up this supposition. Academic literature deals statically with individual aspects and issues in this arena but does not offer a holistic Meta-Analysis attempting to bridge the gap between these elements and to understand 
their interaction in their own context, as well as in the time context expressed by trends. In sum, there are no dynamic studies attempting to describe and critically assess this intangible mechanism. This is deplorable because such a description and assessment are do-able. There is relevant data, even official and hard, which make this pioneering study and very original paper possible and scientifically grounded. It provides semi-conclusions vital for the EU, Europe 2020 and European endeavor working with probably the biggest assets of Europeans - their creativity and values translated into innovations.

\section{LITERATURE BACKGROUND}

Our post-modern, highly competitive, global society depends upon the use of information systems and information technology (IS/IT) (MacGregor Pelikánová, 2013) and consequently on the development and implementation of new technologies. In many aspects, the innovation process matches various already well-described project life cycles which are divided into several stages including initiation, planning, preparatory execution, real execution and closure (Siemieniako \& Gebarowski, 2016).

Since innovations have become an integral part of policies to promote growth (Billon, Marco, \& Lera-Lopez, 2017), the question of the effective and efficient setting of these policies (Turečková \& Nevima, 2017) and their financing emerged. Financial support for R\&D is both necessary and limited, not only by public and private budgetary constraints, limited public budgets and other public factors (Blind, Petersen, \& Riillo, 2017) but also by other challenges embedded in modern technologies (Staníčková, 2015; Melecký, 2013). On one hand, it is assumed that R\&D needs to be financed and that it should lead to innovation activities leading to the transposition and implementation of new technologies in the modern e-business setting and operation (Polanski, 2015). On the other hand, this process includes a myriad of risks and often ends with deadlock. Empirical studies confirm that just a fraction of innovation activities lead to practical results and suggest that often private sector creativity (Zollo, Rialti, Ciappei, \& Boccardi, 2018) and the size of the support by private enterprise is pivotal (Damijan, Kostevc, \& Rojec, 2017).

The EU is a result of economic and political integration focusing on the internal single market with the quartet of freedom of movement (MacGregor Pelikánová, 2017). The EU has always been dominated more by technocratic than political institutions (Lianos, 2010) and the supranational approach has prevailed over the intergovernmental approach. Therefore, the current EU strategy, i.e., the EU strategy for 2010-2020 (Europe 2020) is a supranational, technocratic planning project which sets an impressively ambitious strategic 
goal "to become the most competitive and dynamic knowledge-based economy in the world, capable of sustainable economic growth" (EC, 2010). Europe 2020 is determined to reach this goal via three mutually reinforcing priorities - smart, sustainable and inclusive growth, translated into five headline targets and seven flagship initiatives.

Europe 2020 was issued in 2010 and is marked by economic and other crises issues and by the slump of economic indicators back to 1990s levels (Çolak \& Ege, 2013). Despite this rather deplorable setting, the EU leadership, led by the Barroso Commission, became confident that the EU can, under the auspices of Europe 2020 attain an even higher rate of economic growth than in the US (Balcerzak, 2015).

For the EU and EU policies, such as the European Cohesion Policy, innovation and the use of IS/IT are pivotal (Billon et al., 2017). Europe 2020 deals specifically with R\&D, innovations and digitalization by including them across its five targets. The idea behind it is that economic growth is to be achieved by innovation in the digital environment (Terzić, 2017), which should be the result of the synergy of various EU and EU member state's policies (Kordoš, 2016). In sum, the Barroso European Commission was convinced that without proper R\&D spending, the EU would lose any chance to be amongst the world (economic) leaders (Walburn, 2010).

In 2010, R\&D spending in the EU reached only $1.9 \%$ of GDP, while the rate in the US was $2.6 \%$ and in Japan 3.4\% (Eurostat, 2018). The Barroso Commission was over-confident that $3 \%$ was do-able and key for the digital innovation dominance of the EU in 2020 (EC, 2010). However, eight years later, the reality seems to be different and instead of a dramatically growing trend from $1.9 \%$ to $3 \%$, a rather stagnating trend barely passing $2 \%$ is to be observed at the EU level (Eurostat, 2018). Few studies and analyses have been published about it and its trends; and the reasons (EC, 201; 8b), along with its consequences, are even more obscure in the focus of the academic press (De Noni, Orsi, \& Belussi, 2018; Dima, Begu, Vasilescu, \& Masen, 2018; Potužáková \& Öhm, 2018). In addition, the possibility of a relationship between R\&D spending and innovations, in particular, e-innovations, has not earned any serious interest at all. Do we have a co-relation and what is the consequence of the digital innovation trend?

\section{RESEARCH METHODS}

Data, methods and processes employed in this paper are determined by its aim and the rationale for the study, i.e., they are bound to the three research questions about spending on R\&D; patented inventions, digitalization and 
their possible relation; and existing trends in the EU and in selected EU member states. The selection of EU member states for this study is made by the motivation to be representative and to face the (alleged) cliché about EU member states labeled as "good" (DE, FR), "lazy" PIGS (PT, IT, GR, SP), leaving $(\mathrm{GB})$, particular Scandinavian (DK, FI, SW) and central (AT, CZ, PL).

The performed research entails secondary data while exploring hard data sources, such as Eurostat and the European Patent Office (EPO) databases, official and/or legislative documents, such as Europe 2020, and academic literature. A complementary and merely illustrative glossing is offered based on direct observation, field search and the experience of the author assisting with IP issues for clients for over 20 years and thus participating in many patent applications and other instruments protecting future innovations. Such a conglomerate of diversified and multi-disciplinary data is to be processed by a myriad of appropriately matching methods, both of a quantitative and qualitative nature, and dominated by the holistic Meta-Analysis. Data and methods will vary based on the features of each of the three research questions.

The first question will be addressed by using official data about the ratio of R\&D spending on the GDP during the period 2010-2017 in the EU and selected EU member states, presented by the European Commission and Eurostat. The instrument to do so is the indicator which measures gross domestic expenditure on R\&D as a percentage of the GDP gross domestic product (GERD). This rather numerical indicator will be presented in tables showing what fraction of GDP went on R\&D in the EU and selected EU member states in different years, and so it will allow for both observing trends and to have a firm foundation for a further co-relation study.

The second question has two sub-parts, patented inventions and digitalization, which will be addressed consecutively. Due to the extent and "EU" focus of this study, only "EPO patents," and not merely national patents applicable only in one EU member state, will be included. Namely, an inventor can seek for their invention only a national monopoly in one EU member state, i.e., only one national patent in one single EU member state for the invention. Such patented inventions are locally very limited and not covered by this study. In contrast, this study deals only with inventions filed nationally in one EU member state with a request via EPO for extended protection in other EU member states; i.e., via EPO the request for an "EPO patent" is processed leading to more national patents from various EU member states. The number of applications filed regarding patentable inventions and granted patents is offered by the EPO statistical database (EPO, 2018) and is shown in tables along with data regarding all applications and patents. The success rate calculation will be done on the assumption that the average EPO patent process takes four years (EPO, 2018). Digitalization as a reflection of 
innovation generated, generally by other ideas than patentable inventions, is assessed based on the Digital Economy and Society Index (DESI) and the related Europe's Digital Progress Report (EDPR). DESI is a composite index that summarizes five relevant indicators about Europe's digital performance and tracks the evolution of EU member states in digital competitiveness (EC, 2018a). In other words, DESI is an overall index calculated as the weighted average of the following five main dimensions with the weights selected by the user: 1 . Connectivity (25\%), 2. Human Capital (25\%), 3. Use of the Internet (15\%), 4. Integration of Digital Technology (20\%) and 5. Digital Public Services (15\%) (EC, 2017). The EDPR report combines the quantitative evidence from DESI with country-specific policy insights (EC, 2017).

The third question focuses on the possibility of a relationship between the presented data and the evolution of trends across spending, patents, digitalization and innovation, i.e., GERD, EPO statistics, DESI and EDPR along with proposed less quantified information about innovation, such as observation, informal indices and even propositions presented in EU official documents and academic literature.

We have no perfect data, but we still have sufficient information to address all three questions and move to a higher level, to start to think not only about whether we have a relationship, but whether this is a corelationship or possibly what kind of co-relationship do we have and whether ultimately Europe 2020 is set effectively, efficiently and realistically with respect to innovation as the foundation for competitiveness?

\section{GERD, EPO and DESI and their trends for the entire EU}

The data to address the three research questions include GERD, EPO statistics and DESI, their co-relation and their trends for the EU as such (see Tables 1, 2, 3). These mathematical indicators need to be critically and contextually commented on. The first to be analyzed is the GERD, which logically should grow, because crises have been overcome, more money for R\&D should be available and Europe 2020 and other policies demand it be so.

The results differ from expectations and desires, i.e., GERD for the EU has been growing very little, if at all. Based on the observed trends, the starting point of $1.93 \%$ in 2010 will move to barely more than $2.05 \%$ in 2020 and definitely will not get close to the $3 \%$ threshold. This is an outright failure, which needs to be analyzed and a lesson should be learned from this disappointing experience. This disappointment does not need to have negative consequences if European patent statistics and DESI are satisfactory. 
Table 1. GERD in EU

\begin{tabular}{lll}
\hline Year & GERD (\%) & Comments \\
\hline 2010 & 1.93 & End of crises, stagnation of GERD. \\
2011 & 1.97 & Aftermath of crises and start of the slow growth of GERD. by $0.04 \%$ \\
2012 & 2.01 & Aftermath of crises and continuation of the slow growth of GERD by $0.04 \%$ \\
2013 & 2.02 & Aftermath of crises and continuation of the slow growth of GERD by $0.04 \%$ \\
2014 & 2.03 & Crises overcome, but minimal growth of GERD by $0.01 \%$ \\
2015 & 2.04 & Crises overcome, but minimal growth of GERD by $0.01 \%$ \\
2016 & 2.03 & Crises overcome, but a decrease of GERD by $0.01 \%$
\end{tabular}

Source: author based on publicly available data (Eurostat, 2018).

Table 2. EPO patents

\begin{tabular}{lllllll}
\hline Year & $\begin{array}{l}\text { Applications } \\
\text { from the EU }\end{array}$ & $\begin{array}{l}\text { All } \\
\text { applications }\end{array}$ & $\begin{array}{l}\text { Share of } \\
\text { applications } \\
\text { from the EU } \\
\text { of all } \\
\text { applications }\end{array}$ & $\begin{array}{l}\text { Granted } \\
\text { patents for } \\
\text { Inventions } \\
\text { from the EU }\end{array}$ & $\begin{array}{l}\text { All granted } \\
\text { patents }\end{array}$ & $\begin{array}{l}\text { Share } \\
\text { of EU } \\
\text { patents } \\
\text { on all } \\
\text { patents }\end{array}$ \\
\hline 2010 & 66637 & 151015 & $44 \%$ & 27903 & 58117 & $48 \%$ \\
2011 & 64379 & 142822 & $45 \%$ & 29594 & 62108 & $47 \%$ \\
2012 & 65171 & 148562 & $44 \%$ & 29573 & 65655 & $45 \%$ \\
2013 & 65631 & 148027 & $44 \%$ & 30426 & 66707 & $46 \%$ \\
2014 & 67393 & 152703 & $44 \%$ & 29775 & 64613 & $46 \%$ \\
2015 & 67692 & 160004 & $42 \%$ & 32894 & 68419 & $48 \%$ \\
2016 & 67405 & 159316 & $42 \%$ & 44042 & 95940 & $46 \%$ \\
2017 & 69138 & 165590 & $42 \%$ & 45888 & 105635 & $43 \%$ \\
\hline
\end{tabular}

Source: author based on publicly available data (EPO, 2018).

The number of patent applications, i.e., inventions from Europeans to the EPO with the request to grant patent protection for the EU, has been growing since 2011 with an annual increase of $1-2 \%$. Since the total number of applications, i.e., applications from the entire world, has generally been growing faster and, e.g., from 2016 to 2017 even by 4\%, the share of applications from Europeans filed with the EPO on the total bulk of applications dropped from $44 \%$ to $42 \%$. This implies that, although the number of European inventions presented for patent protection in the EU has been growing, the number of inventions from other countries has risen even faster.

The number of granted patents, i.e., successful inventions from Europeans presented to the EPO with the request to grant patent protection for the EU, had been both increasing and decreasing until 2015. Since 2016, there is an unprecedented growth in the number of patents granted by 
EPO to applicants from the EU, which exceeds even $33 \%$ annually. A similar trend is detectable by all granted patents. The share of patents granted to EU applicants from all patents granted by EPO has been dropping from $48 \%$ to $43 \%$. Assuming that the average patent application proceedings takes four years (EPO, 2018), then the 66,637 applications from the EU applicants in 2010 have to be matched with 29,775 granted patents in 2014, i.e., a success rate of $45 \%$. The data looks very different after 2015 , and the 65,631 applications from the EU applicants in 2013 have to be matched with 45,888 granted patents in 2017 , i.e., an unbelievable success rate of $70 \%$. This rather wide-ranging data and related trends are confronted by data on other types of ideas for innovations covered by DESI.

Table 3. DESI for the EU

\begin{tabular}{|c|c|c|c|}
\hline Year & $\begin{array}{l}\text { DESI - all five } \\
\text { indicators } \\
(\%)\end{array}$ & $\begin{array}{l}\text { DESI - integration of } \\
\text { digital technology }(\%)\end{array}$ & Comments \\
\hline 2014 & 44 & 28 & \\
\hline 2015 & 47 & 32 & $\begin{array}{l}\text { The importance of High-Performance Computing for the } \\
\text { competitiveness of European science and industry. }\end{array}$ \\
\hline 2016 & 52 & 34 & $\begin{array}{l}\text { EU and EU member states have identified the uptake of } \\
\text { digitization by industry as a priority. }\end{array}$ \\
\hline 2017 & 51 & 37 & $\begin{array}{l}\text { Social media, elnvoices and mobile applications have } \\
\text { been driving the digital transformation of European } \\
\text { businesses. }\end{array}$ \\
\hline 2018 & 54 & 40 & \\
\hline
\end{tabular}

DESI, with all its five indicators, has been slowly growing. However, it is worthwhile observing that the 4th indicator, integration of digital technology, remains slightly behind, but grows faster. In other words, the trend has a higher progression speed, but the starting point was much lower for this particular indicator. This cannot be underestimated, because the 4th indicator includes business digitalization and e-commerce, which are pivotal for competitiveness on the global market (MacGregor Pelikánová, 2013). Naturally, this data provides a generalized, and not sufficiently deep, insight and hence needs to be complemented by data linked to the selected EU member states.

\section{GERD, EPO and DESI and their trends for selected EU member states}

First to be analyzed is the GERD indicator for the selected EU member states while keeping in mind that the expected $3 \%$ threshold seems unrealistic at the EU level, i.e., the average for the EU was 1.93\% in 2010 and climbed only 
to $2.03 \%$ in 2016 (see Table 4). So how did selected EU member states do, shall we find differences between them and what are their trends?

Table 4. GERD in EU member states (\%) - note: $N C=$ not confirmed

\begin{tabular}{llllllllllllll}
\hline \multicolumn{1}{c}{ AT } & CZ & DE & DK & ES & FI & FR & GB & GR & IT & PL & PT & SW \\
\hline 2010 & 2.73 & 1.34 & 2.71 & 2.92 & 1.35 & 3.73 & 2.18 & 1.67 & 0.60 & 1.22 & 0.72 & 1.53 & 3.22 \\
2011 & 2.67 & 1.56 & 2.80 & 2.94 & 1.33 & 3.64 & 2.19 & 1.67 & 0.67 & 1.21 & 0.75 & 1.46 & 3.25 \\
2012 & 2.91 & 1.78 & 2.87 & 2.98 & 1.29 & 3.42 & 2.23 & 1.60 & 0.70 & 1.27 & 0.88 & 1.38 & 3.28 \\
2013 & 2.95 & 1.9 & 2.82 & 2.97 & 1.27 & 3.29 & 2.24 & 1.65 & 0.81 & 1.31 & 0.87 & 1.33 & 3.31 \\
2014 & 3.07 & 1.97 & 2.87 & 2.91 & 1.24 & 3.17 & 2.23 & 1.67 & 0.83 & 1.34 & 0.94 & 1.29 & 3.15 \\
2015 & 3.05 & 1.93 & 2.92 & 2.96 & 1.22 & 2.90 & 2.27 & 1.67 & 0.97 & 1.34 & 1.00 & 1.24 & 3.27 \\
2016 & 3.09 & NC & 2.94 & NC & 1.19 & 2.75 & NC & 1.69 & 1.01 & NC & NC & 1.27 & 3.27 \\
\hline 5
\end{tabular}

Source: author based on publicly available data (Eurostat, 2018).

Both the GERD indicator and its evolution trends were dramatically different in the selected EU member states. From 2010 to 2015, resp. 2016, the GERD indicator grew (AT, CZ, DE, PL), stagnated (DK, FR, GB, SW) and even fell (ES, FI, PT). The difference between the best and worst from the sample for 2010 was $3.22(\mathrm{SW})-0.60(\mathrm{GR})=2.62$ and from the sample for 2015 was $3.27(\mathrm{SW})-0.97(\mathrm{GR})=2.30$. Generally, the differences have diminished just gently and, except for Scandinavia, Germany and Austria, the 3\% threshold seems unattainably high. This means that even model EU member states, such as France, breach Europe 2020 targets and under-financed R\&D, i.e., they jeopardize the innovation process. Does this (allegedly) insufficient financial support cripple patentable innovations, i.e., inventions, and/or other innovations, especially in the digital universe?

At the EU level, presenting an invention and filing it with EPO with a request for granting a patent, does not automatically point to the innovation boost (Table 5). Nevertheless, it is a component of the innovation landscape. Since, pursuant to the GERD indicator, there is not a dramatic increase in the financial support for both, patent and digital, branches of R\&D leading to materialized inventions, it is valuable to observe the number of "patent attempts" in the selected EU member states during the observed period of 2010-2017.

The differences between the GERD indicators are just miniscule compared to differences between filed patent applications. In 2010, only 83 applications from Greece were to be contrasted with 27,328 applications from Germany and in 2017, only 100 from Greece compared with Germany's 25,490. This means that 329 times, resp. 255 times more applications for an EPO patent came from Germany. 
Table 5. EPO patent applications filed by applicants from selected EU member states

\begin{tabular}{llllllllllllll}
\hline & AT & CZ & DE & DK & ES & FI & FR & GB & GR & IT & PL & PT & SW \\
\hline 2010 & 1744 & 167 & 27328 & 1872 & 1430 & 1617 & 9575 & 5381 & 83 & 4078 & 205 & 81 & 3590 \\
2011 & 1734 & 162 & 26202 & 1782 & 1404 & 1548 & 9617 & 4746 & 78 & 3970 & 246 & 81 & 3638 \\
2012 & 1874 & 140 & 27249 & 1605 & 1544 & 1851 & 9897 & 4716 & 79 & 3744 & 383 & 76 & 3581 \\
2013 & 1993 & 151 & 26510 & 1942 & 1504 & 1894 & 9835 & 4587 & 68 & 3706 & 372 & 95 & 3674 \\
2014 & 1964 & 167 & 25663 & 1983 & 1471 & 2182 & 10614 & 4764 & 95 & 3649 & 482 & 113 & 3873 \\
2015 & 1989 & 213 & 24807 & 1920 & 1581 & 1993 & 10760 & 5051 & 91 & 3986 & 566 & 141 & 3839 \\
2016 & 2046 & 190 & 25012 & 1869 & 1560 & 1820 & 10504 & 5188 & 74 & 4172 & 411 & 158 & 3555 \\
2017 & 2213 & 205 & 25490 & 2114 & 1676 & 1818 & 10559 & 5313 & 100 & 4352 & 469 & 149 & 3728 \\
\hline
\end{tabular}

Source: author based on publicly available data (EPO, 2018).

Until 2015, the number of applications grew, but filing for a patent does not mean one is granted. So how many EPO patents were granted?

Table 6. EPO granted patents based on applications filed by applicants from selected EU member states

\begin{tabular}{llllllllllllll}
\hline & AT & CZ & DE & DK & ES & FI & FR & GB & GR & IT & PL & PT & SW \\
\hline 2010 & 671 & 45 & 12550 & 515 & 392 & 679 & 4540 & 1851 & 16 & 2287 & 44 & 28 & 1460 \\
2011 & 737 & 56 & 13578 & 592 & 381 & 587 & 4802 & 1946 & 29 & 2286 & 45 & 26 & 1489 \\
2012 & 796 & 56 & 13315 & 565 & 405 & 669 & 4804 & 2020 & 31 & 2237 & 80 & 30 & 1572 \\
2013 & 837 & 67 & 13425 & 608 & 395 & 665 & 4910 & 2064 & 30 & 2353 & 95 & 26 & 1789 \\
2014 & 891 & 66 & 13086 & 599 & 467 & 633 & 4728 & 2072 & 23 & 2274 & 108 & 22 & 1705 \\
2015 & 1040 & 74 & 14114 & 698 & 511 & 744 & 5426 & 2094 & 22 & 2476 & 151 & 46 & 1936 \\
2016 & 1370 & 95 & 18728 & 1033 & 752 & 1081 & 7032 & 2931 & 39 & 3207 & 180 & 59 & 2661 \\
2017 & 1465 & 123 & 18813 & 1076 & 805 & 1230 & 7325 & 3116 & 36 & 3111 & 216 & 68 & 2903 \\
\hline
\end{tabular}

The number of granted patents, i.e., successful inventions from selected EU member states presented to the EPO with the request to grant patent protection for the EU, had been both rising and falling until 2015 (see Table 6). Then there was a jump between 2015 and 2016, which in the majority (but not all, see, e.g. Italy) of the selected states continued with an increase in 2017. Assuming that the average patent application proceedings takes 4 years (EPO, 2018), then e.g. 1,744 (AT), 27,328 (DE), 9,575 (FR) or 205 (PL) applications in 2010 have to be matched against 891 (AT), 13,086 (DE), 4,728 (FR) or 108 (PL) granted in 2014 , i.e., the success rate is $51 \%$ (AT), $48 \%$ (DE), $49 \%$ (FR) or $52 \%$ $(\mathrm{PL})$. Is this matched as well by other ideas leading to innovation? 
Table 7. DESI index (all five indicators) in selected EU member states in 2014-2016

\begin{tabular}{|c|c|c|c|c|c|c|c|c|c|c|c|c|c|}
\hline & AT & $\mathrm{CZ}$ & $\mathrm{DE}$ & DK & ES & $\mathrm{FI}$ & FR & GB & GR & IT & $\mathrm{PL}$ & PT & SW \\
\hline 2014 & & 42 & 49 & 65 & 44 & 59 & 45 & 52 & 31 & 33 & 36 & 44 & 63 \\
\hline 015 & & 46 & 51 & 68 & 49 & 62 & 48 & 55 & 36 & 36 & 38 & 46 & 66 \\
\hline 16 & 58 & 50 & 57 & 68 & 52 & 67 & 51 & 61 & 37 & 40 & 43 & 53 & 67 \\
\hline
\end{tabular}

Source: author based on publicly available data (EC, 2015).

DESI, with all its five indicators, has been growing in the EU and in all selected EU member states (Table 7). The speed of growth varies both across the $\mathrm{EU}$ and across time, while the spread (difference) remains similar, e.g., between Greece and Sweden, it was 63-31=32 in 2014 and 67-37=30 in 2016. Not only Greece but Italy as well remained, regarding digitalization, far behind the Czech Republic and Poland. For the EU sadly, Great Britain did better than the EU internal tandem (DE and FR). Regarding digitalization and innovations, the EU should think twice before criticizing the allegedly "problematic" Great Britain and "behind post-communistic" Czech Republic and Poland, before showing any admiration with respect to "creative" France and "hard-working" Germany and before playing other national stereotypes (Hřebičková, Mottus, Graf, Jelinek, \& Realo, 2018), and before treating the PIGS states, especially Greece, as digitalization-eager destinations. The proclaimed harmonization is not matched by the results and, if a model should be followed, then it should be the Scandinavian one. However, wouldn't that be too expensive? Let's examine the relationship between spending, patents, digitalization and innovations in general.

\section{The co-relation of GERD, EPO and DESI and related trends in the EU and selected EU member states}

Considering the nature of IP and the fact that innovations are significantly generated by patented inventions and/or ideas for the digital universe, and that they usually all need strong financial support, the data provided above is highly relevant. Nevertheless, the ephemeral features of IP, and the inherent difficulty to describe and measure all aspects of such unpredictable outcomes as inventions, point to the inconclusiveness and partial weakness of the provided propositions. To offset this unavoidable imprecision, the provided statistical and time review is complemented by a dynamic review focusing on the possible relationship of this data and trends. Firstly, an overview of all involved data for each year $(2014,2015,2016)$ is presented, employing the GERD, patent applications and patent grant number, and DESI (see Tables 8 , $9,10)$. Secondly, an overview of their growth, stagnation and decrease will 
be presented. This will allow one to assess their possible relationship and pertinent trends.

Table 8. GERD, EPO and DESI in the EU and selected EU member states in 2014

\begin{tabular}{lllllllllllllll}
\hline $\mathbf{2 0 1 4}$ & EU & AT & CZ & DE & DK & ES & FI & FR & GB & GR & IT & PL & PT & SW \\
\hline GERD & 2.03 & 3.07 & 1.97 & 2.87 & 2.91 & 1.24 & 3.17 & 2.23 & 1.67 & 0.86 & 1.34 & 0.94 & 1.29 & 3.15 \\
Pat. & 67393 & 1964 & 167 & 25663 & 1983 & 1471 & 2182 & 10614 & 4764 & 95 & 3649 & 482 & 113 & 3873 \\
App. & & & & & & & & & & & & & & \\
Pat. & 29775 & 891 & 66 & 13086 & 599 & 467 & 633 & 4728 & 2072 & 23 & 2274 & 108 & 22 & 1705 \\
Gran. & & & & & & & & & & & & & & \\
DESI & 44 & 46 & 44 & 51 & 65 & 45 & 60 & 46 & 54 & 31 & 34 & 38 & 46 & 65
\end{tabular}

Source: author based on publicly available data (Eurostat, 2018 and EPO, 2018).

Regarding 2014, it needs to be pointed out that the GERD was way under the threshold of $3 \%$ for the vast majority of EU member states and even the EU as such and even the DESI often stayed below 50 . The ratio between patent applications and patents granted was 2:1, i.e., an EPO patent success rate of $50 \%$ (naturally, this should be further re-calculated based on the expected four years' proceeding gap). The following year, 2015, provides a similar insight.

Table 9. GERD, EPO and DESI in the EU and selected EU member states in 2015

\begin{tabular}{lllllllllllllll}
\hline 2015 & EU & AT & CZ & DE & DK & ES & FI & FR & GB & GR & IT & PL & PT & SW \\
\hline GERD & 2.04 & 3.05 & 1.93 & 2.92 & 2.96 & 1.22 & 2.90 & 2.27 & 1.67 & 0.97 & 1.34 & 1.00 & 1.24 & 3.27 \\
Pat. & 67692 & 1989 & 213 & 24807 & 1920 & 1581 & 1993 & 10760 & 5051 & 91 & 3986 & 566 & 141 & 3839 \\
$\begin{array}{l}\text { App. } \\
\text { Pat. }\end{array}$ & 32894 & 1040 & 74 & 14114 & 698 & 511 & 744 & 5426 & 2094 & 22 & 2476 & 151 & 46 & 1936 \\
$\begin{array}{l}\text { Gran. } \\
\text { DESI }\end{array}$ & 47 & 48 & 46 & 51 & 68 & 49 & 62 & 48 & 55 & 36 & 36 & 38 & 46 & 66
\end{tabular}

Source: author based on publicly available data (Eurostat, 2018 and EPO, 2018).

Indeed, in 2015, the GERD remained far from 3\%, while the DESI was slowly getting close to 50 and the EPO success rate stayed with $50 \%$. However, 2016 saw a big change.

Table 10. GERD, EPO and DESI in the EU and selected EU member states in 2016

\begin{tabular}{|c|c|c|c|c|c|c|c|c|c|c|c|c|c|c|}
\hline 2016 & EU & AT & $\mathrm{CZ}$ & $\mathrm{DE}$ & DK & ES & FI & FR & GB & GR & IT & PL & PT & SW \\
\hline$\overline{\text { GERD }}$ & 2.03 & 3.09 & $\mathrm{NC}$ & 2.94 & $\mathrm{NC}$ & 1.19 & 2.75 & NC & 1.69 & 1.01 & $\mathrm{NC}$ & NC & 1.27 & 3.27 \\
\hline $\begin{array}{l}\text { Pat. } \\
\text { App. }\end{array}$ & 67405 & 2046 & 190 & 25012 & 1869 & 1560 & 1820 & 10504 & 5188 & 74 & 4172 & 411 & 158 & 3555 \\
\hline $\begin{array}{l}\text { Pat. } \\
\text { Gran. }\end{array}$ & 44042 & 1370 & 95 & 18728 & 1033 & 752 & 1081 & 7032 & 2931 & 39 & 3207 & 180 & 59 & 2661 \\
\hline DESI & 52 & 58 & 50 & 57 & 68 & 52 & 67 & 51 & 61 & 37 & 40 & 43 & 53 & 67 \\
\hline
\end{tabular}

Source: author based on publicly available data (Eurostat, 2018 and EPO, 2018). 
Although in 2016, the GERD and DESI stayed the same or increased by an insignificant margin, the patent success rate made a historic and unprecedented jump. A good visualization is provided by Table 11, which does not repeat the above data but for the period 2014-2016 merely puts " + " if there is an increase in the given parameter (GERD, patent applications, patent granted, DESI), " 0 " if there is stagnation or an insignificant increase or decrease and "-" if there is a drop.

Table 11 presents an important insight regarding the spending on R\&D and an ephemeral possibility relationship with innovation trends in the EU and selected member states. Based on this overview, innovations, based both on patents and digitalization, are growing despite the lack of growth in spending on R\&D and in patent applications. However, it would be superficial and controversial to stop here. This data is correct, but it needs to be understood holistically and the full Meta-Analysis must be performed, appreciated and discussed in the context of other data, especially that provided by academic literature.

Table 11. GERD, EPO and DESI in the EU and selected EU member states trend 2014-2016 - note: evolution of the given parameter " + " (increase), " 0 " (stagnation), "-" (decrease)

\begin{tabular}{lllllllllllllll}
\hline & EU & AT & CZ & DE & DK & ES & FI & FR & GB & GR & IT & PL & PT & SW \\
\hline GERD & 0 & 0 & - & + & + & - & - & + & + & + & 0 & + & 0 & + \\
Pat. & 0 & + & 0 & 0 & - & 0 & - & 0 & + & 0 & + & 0 & + & - \\
App. & & & & & & & & & & & & & & \\
Pat. & + & + & + & + & + & + & + & + & + & + & + & + & + & + \\
Gran. & & + & + & + & + & & & & & & & & & \\
DESI & + & + & + & + & + & + & + & + & + & + & + & + & + & + \\
\hline
\end{tabular}

\section{RESULTS AND DISCUSSION}

The performed research, extraction and presentation of data along with other information, often dispersedly presented in EU official or semi-official documents and academic literature, allows for laying out solid academic results, implied and accompanied by a proper discussion done consecutively and based on the three research questions. In addition, patterns can be observed while considering EU member state particularities and this suggests that in the diversified world of innovation the EU member states' drive, commitment, effectiveness and efficiency to innovations is growing (De Noni 
et al., 2018), while R\&D spending and differences between EU member states do not change dramatically.

First off, there is no doubt that public and private R\&D symbiosis is pivotal for innovation (Hammadou, Paty, \& Savona, 2014) and that a smaller fraction of GDP went, goes and will continue to go towards R\&D in the EU, and in the majority of EU member states, than in the USA or Japan. The Europe 2020 threshold of $3 \%$ is a chimera and the GERD evolution does not create any legitimate grounds for hope for a dramatic change. Similarly, a plain academic and field observation (Bourgeais \& Gebhard, 2015), and recent news and issues in the EU, do not offer any reasons or foundations for a jump from $2 \%$ to $3 \%$ by 2020 . Even more interestingly, and beyond the issue of innovation, is the implied impression that EU-required parameters might be more likely met by those states that are not labeled as model states, rather than by the 'illustrious tandem,' France-Germany. In 2015, the EU had on average only $2.04 \%$, France only $2.27 \%$ and the allegedly highly improving Greece $0.97 \%$, while the Scandinavia was close to or even above $3 \%$. This confirms previous predictions that the full satisfaction of targets of Europe 2020 will not be met in 2020 (MacGregor Pelikánová, 2017). However, this does not imply per se that innovations (Roszkowska-Menkes, 2017) and competitiveness in the EU must be jeopardized (Jones \& Tahri, 2011). For such dramatic conclusions, we would need to see "bad" data regarding patents and digitalization (Polanski, 2015) with a declining trend.

Secondly, the number of patent applications has not changed dramatically during the observed period and the implied trend indicates stagnation, while the number of granted patents increased dramatically and the success rate jumped from $40-50 \%$ to over $70 \%$. This asymmetric evolution in one innovation branch (patent), which was probably caused by the internal EPO policy changes, is paralleled by the steady, though slow, growth in another innovation branch (digitalization - DESI).

Thirdly, two plausible relationships were established - (i) between patent applications and patents granted (see, e.g. Greece and Germany) and (ii) between GERD and DESI (see Scandinavia). However, the related trends weaken the importance of these relations, because the patent success rate jumps and DESI grows for all, i.e., even with a decrease in GERD, an increase in DESI takes place over time. It can merely be proposed that the possibility of the relationship is rather weaker and that, due to the observed trends, increased spending on R\&D in the EU is only one of many various factors and preconditions for innovation. In addition, results and trends in the EU are nationally particular and these particularities (Hammadou et al., 2014) do not often match well-known clichés. Based on the parameters explored by this paper, Scandinavia appears more effectively and efficiently oriented 
towards innovations than France, while central European countries (AT, CZ, $\mathrm{PL}$ ) have been progressing better towards innovations than good "old" EU members from the South (ES, GR, IT, PT). Nevertheless, some well-known generalization statements can be confirmed by this paper. For example, the German drive towards filing for patents and getting patents (Germany has 2 times more than France, 5 times more than Italy and 20 times more than Spain) matches with the German organization and determination regarding innovations and even in other fields. A less optimistic example of the confirmation of a generalized statement is the sad revelation that the "PIGS" states (PT, IT, GR, ES) are lagging behind, with respect to Eurozone crises and other financial issues, in addition to innovation.

In sum, GERD values and trends are smaller, slower and more diversified than perhaps generally expected, while numbers of patents and digitalization are growing, the alleged relationship between R\&D and patent statistics and DESI/EDPR seems more ephemeral, i.e., the R\&D spending curve is only partially paralleled by curves indicating innovation trends. An increase in R\&D spending might, but does not need to, generate an increase in innovation trend in the EU. This all contributes to the conclusion that the EU is less harmonized and harmonization-ready for innovation than expected (MacGregor Pelikánová, 2017) and desired by EU leaders and policymakers. Europe 2020 was probably set effectively (a 3\% threshold is correct and in tune with world recommendations) and efficiently (putting innovation in a strategic document Europe 2020 is the right process), but hardly efficiently and realistically. Innovations are critical for the EU's competitiveness and the success of the single internal market and the reduction of differences and the general progress in both patents and digitalization in all EU member states is highly desirable. This all seems rather far away from now and the selected pathway seems to fit it rather poorly.

\section{CONCLUSION}

Innovation is clearly indispensable for global competitiveness and its, often expensive, foundation can take many shades and shapes and can be a product of academic, business and even users activities (RoszkowskaMenkes, 2017). Innovation is often protected as invention by patent or as an idea transformed in copyrightable work. The data is not perfect, but there is still sufficient information to address all three questions and move to a higher level; to start to think not only whether there is a possible relationship, but also what values and kinds of co-relations already exist and whether they are desirable in the EU and its member states. 
Based on the performed multi-disciplinary search and holistic MetaAnalysis, the following answers to all three research questions are proposed. Firstly, the $3 \%$ threshold is not going to be met in the larger part of the EU, large differences in GERD between EU member states remain, and the model is to be found in Scandinavia rather than in the internal top EU tandem (DE, FR). Secondly, despite the lack of an increase in the fraction of GDP allocated to R\&D spending, the number of granted patents via EPO keeps growing along with digitalization across the EU. Hence, the failure to meet the $3 \%$ threshold and to see a growing GERD is not bad per se for innovations in the EU. Thirdly, the possibility of a relationship between these factors and trends appears to exist, but this is not conclusive or dramatically strong. Spending more money and filling more patent applications, etc. appears to contribute to the innovation trend in the EU but it is not per se self-salvaging.

These answers are proposed and definitely are inconclusive due to the limitations of the performed and presented study. One set of limitations is inevitably caused by the intangible, ephemeral and hardly predictable nature of innovations and the impossibility to collect and mathematically process all involved phenomena. In addition, due to the limited scope of this paper and the availability of Eurostat and EPO data, the presented study focused only on innovations reaching the status of European innovations and reflecting inventions or digitalization during the past few years. It included neither innovations linked to other IP assets, such as trade secrets or design or utility models, or certain types of copyright, nor strictly national innovations, such as national patents, which may grow to EU importance, nor information regarding 2017 and 2018. Nevertheless, the dynamics offered by the research and the provided cross-support of data and arguments leading to answers to all three research questions make the provided propositions academically acceptable and offers the potential for further research study, which should reduce the mentioned limitations and shortcomings.

Further, the presented results and discussion generate additional original suggestions, such as that the differences between EU member states regarding innovations do not vanish, that although the Europe $20203 \%$ threshold is not going to be met, that the number of patented inventions and the practical digitalization can still grow across the EU, and that EU member states carry many over-looked, nationally-based particularities (De Noni et al., 2018). This implies a number of new burning questions need to be answered in order to enhance awareness, to re-adjust the EU approach to innovations and to EU member states' potential to generate innovations, and to make the innovation process in the entire EU more effective and efficient.

Right now, the targets set by Europe 2020, such as the 3\% threshold, are perhaps effective but are definitively not efficient and realistic. Innovations 
are foundations for competitiveness and at the same time they are the result of creative endeavors reflecting authors and inventors. After all, work is an image of its author, the European civilization is based on Christianity and creative work, and over-regulation suffocates creative activities which money cannot overcome. The motto of the EU "In varietate concordia" (United in diversity) matches perfectly to it.

\section{Acknowledgments}

This contribution was supported by GA ČR No. 17-11867S “Comparison of the interaction between the law against unfair competition and intellectual property law, and its consequences in the central European context."

\section{References}

Balcerzak, A.P. (2015). Europe 2020 Strategy and structural diversity between old and new member states, application of zero unitarization method four dynamic analysis in the years 2004-2013. Economics and Sociology, 8(2), 190-210.

Billon, M., Marco, R., \& Lera-Lopez, F. (2017). Innovation and ICT use in the EU: An analysis of regional drivers. Empirical Economics, 53(3), 1083-1108.

Blind, K., Petersen, S., \& Riillo, C.A.F. (2017). The impact of standards and regulation on innovation in uncertain markets. Research Policy, 46, 249-264.

Bourgeais, V., \& Gebhard, F. (2015). How is the European Union progressing towards its Europe 2020 targets? Eurostat Newsrelease, 38, 2015.

Çolak, M.S., \& Ege, A. (2013). An assessment of EU 2020 strategy: Too far to reach? Social Indicators Research, 110(2), 659-680.

Damijan, J., Kostevc, Č., \& Rojec, M. (2017). Exporting status and success in innovation: Evidence from CIS micro data for EU countries. The Journal of International Trade \& Economic Development, 26(5), 585-611.

De Noni, I., Orsi, L., \& Belussi, F. (2018). The role of collaborative networks in supporting the innovation performances of lagging-behind European regions. Research Policy, 47, 1-13.

Dima, A.M., Begu, L., Vasilescu, M.D., \& Maasen, M.A. (2018). The relationship between the knowledge economy and global competitiveness in the EU. Sustainability, 10(6), 1-15.

European Commission (2018a). DESI. Retrieved 22 September, 2018, from https://ec.europa.eu/digital-single-market/en/desi and https://digitalagenda-data.eu/datasets/desi/visualizations and https://ec.europa.eu/ digital-single-market/en/progress-country

European Commission (2018b). Eurostat - R\&D expenditure. Retrieved 22 September, 2018, from https://ec.europa.eu/eurostat/statisticsexplained/index.php/R_\&_D_expenditure 
European Commission (2017). Commission staff working document. Europe's digital progress report. Retrieved 30 June, 2018, from https://ec.europa. eu/digital-single-market/en/news/europes-digital-progressreport-2017

European Commission (2015). DESI. Retrieved 30 June, 2018, from https:// ec.europa.eu/digital-single-market/en/news/desi-2015-country-profiles

European Commission (2010). Communication from the Commission Europe 2020. A strategy for smart, sustainable and inclusive growth. Retrieved 30 June, 2018, from http://ec.europa.eu/eu2020/pdf/COMPLET\%20 EN\%20BARROSO\%20\%20\%20007\%20-\%20Europe\%202020\%20-\%20 EN\%20version.pdf

European Patent Office (2018). Statistics. Retrieved 30 June, 2018, from http://www.epo.org/about-us/annual-reports-statistics/statistics.html

Eurostat (2018). Gross domestic expenditure on R\&D (GERD). Retrieved 30 June, 2018, from http://ec.europa.eu/eurostat/tgm/table.do?tab=table \&init=1\&language=en\&pcode=t2020_20\&plugin=1

Hammadou, H., Paty, S., \& Savona, M. (2014). Strategic interactions in public R\&D across European countries: A spatial econometric analysis. Research Policy 43, 1217-1226.

Hřebíčková, M., Mottus, R., Graf, S., Jelínek, M., \& Realo, A. (2018). How accurate are national stereotypes? A test of different methodological approaches. European Journal of Personality, 32(2), 87-99.

Jones, R., \& Tahri, D. (2011). Online selling and contracting. An overview of EU data rules. Computer Law \& Security Review, 27(4), 402-406.

Kalanje, Ch. (2018). Role of Intellectual Property in Innovation and New Product Development. WIPO. Retrieved 30 June, 2018, from http://www. wipo.int/sme/en/documents/ip_innovation_development_fulltext.html Kordoš, M. (2016). Effects of the EU competition policy and strategy symbiosis (pp. 472-479). In International Conference on European Integration. Ostrava: VŠB-TU Ostrava, Faculty of Economics.

Lianos, I. (2010). Shifting narratives in the European internal market: Efficient restrictions of trade and the nature of "economic" integration. European Business Law Review, 21(5), 705-760.

MacGregor Pelikánová, R. (2017). European myriad of approaches to parasitic commercial practices. Oeconomia Copernicana, 8(2), 167-180.

MacGregor Pelikánová, R. (2014). The dis(harmony) of opinions regarding domain names in the Czech Republic. Scientific Papers of the University of Pardubice, Series D 3/2014, 32(3), 73-84.

MacGregor Pelikánová, R. (2013). Internet my Dearest, what type of European integration is the clearest? Acta Universitatis Agriculturae et Silviculturae Mendelianae Brunensis, 61(7), 2475-2481.

Melecký, L. (2013). Use of DEA approach to measuring efficiency trend in old EU Member States (pp. 381-390). In 11th International Conference on Liberec Economic Forum. Sychrov, Czech Republic, September 16-17, 2013. OECD (2015). Frascati Manual 2015: Guidelines for Collecting and Reporting Data on Research and Experimental Development, The Measurement of 
Scientific, Technological and Innovation Activities. Paris: OECD Publishing. Retrieved 30 June, 2018, from https://www.oecd-ilibrary.org/scienceand-technology/frascati-manual-2015_9789264239012-en. http://dx.doi. org/10.1787/9789264239012-en

Pakšiová, R. (2016). Understanding of corporate social responsibility in large companies in Slovakia within the context of a sustainable development (pp. 516-525). In Economic Policy in the European Union Member Countries. Karviná: School of Business Administration in Karvina, SU in Opava.

Polanski, P.P. (2015). Towards the single digital market for e-identification and trust services. Computer Law \& Security Review, 31(6), 773-781.

Polcyn, J. (2018). Human development level as a modifier of education efficiency. Management-Poland, 22(2), 171-186.

Potužáková, Z., \& Öhm, J. (2018). R\&D investments, EPO patent applications and the economic heterogeneity within the EU. Review of Economic Perspectives, 18(2), 177-191.

Roszkowska-Menkes, M. (2017). User innovation: State of art and perspectives for future research. Journal of Entrepreneurship, Management and Innovation, 13(2), 127-154.

Siemieniako, D., \& Gebarowski, M. (2016). How can developers of shopping centre projects stimulate the customers'experiences at trade fairs (pp. 2010-220). In I. Smberova, F. Milichovsky, \& O. Zizlavsky (Eds.), 21st International Scientific Conference on Smart and Efficient Economy Preparation for the Future Innovative Economy. Czech Republic: Brno Univ Technol, Fac Business \& Management.

Staníčková, M. (2015). Classifying the EU competitiveness factors using multivariate statistical methods (pp. 313-320). In 2nd Global Conference on Business, Economics and Management and Tourism (BEMTUR). Czech Republic: Procedia Economics and Finance.

Terzić, L. (2017). The role of innovation in fostering competitiveness and economic growth: Evidence from developing economies. Comparative Economic Research, 20(4), 65-81.

Turečková, K., \& Nevima, J. (2017). Cluster analysis in context of ICT sector in NUTS 3 regions of Czech Republic (pp. 313-320). In Proceedings of the 13th International Conference Liberec Economic Forum 2017. Liberec: Technical University of Liberec.

Walburn, D. (2010). Europe 2020. Local Economy, 25(8), 699-702.

Zollo, L., Rialti, R., Ciappei, C., \& Boccardi, A. (2018). Bricolage and social entrepreneurship to address emergent social needs: a "deconstructionist" perspective. Journal of Entrepreneurship, Management and Innovation, 14(2), 19-47. 


\section{Abstrakt}

Zrównoważonego rozwoju i konkurencyjności nie da się osiagnqć w naszym wysoce konkurencyjnym, globalnym społeczeństwie bez innowacji. Innowacje sq zazwyczaj wynikiem wymagajqcego finansowo procesu badawczego, który generuje aktywa zwiqzane z własnościq intelektualnq, a mianowicie opatentowanych wynalazków lub pomysłów na cyfryzację i chronionych prawem autorskim lub $w$ inny sposób. UE zdaje sobie z tego sprawę, a jej obecna strategia, Europa 2020, stwierdza, że 3\% PKB powinno zostać przeznaczone na badania i rozwój najpóźniej do 2020 r., co powinno zwiększyć poziom innowacyjności i uczynić UE czołowym światowym liderem gospodarczym. Niewątpliwie innowacja jest niezbędna i musi być finansowana. Jednak zwiqzek między zaangażowanymi czynnikami a zwiqzanq z tym dynamika jest niejasny i nie otrzymat wystarczajqcej uwagi naukowej i akademickiej. Aby uczynić pierwszy krok do rozwiqzania problemu, należy odpowiedzieć na trzy pytania badawcze. Po pierwsze, jakq część PKB przeznacza się na badania i rozwój, wyrażonych przez GERD, i jaki jest trend GERD w UE i wybranych państwach członkowskich UE? Po drugie, ile złożono europejskich wniosków patentowych i przyznano patenty, jaki był wskaźnik sukcesu i jak postępuje cyfryzacja w UE i wybranych państwach członkowskich UE i jakie sq trendy? Po trzecie, czy można implikować możliwość zwiqzku między nimi? Odpowiedzi na te trzy pytania opieraja się na interdyscyplinarnych badaniach wykorzystujqcych twarde źródła danych, takich jak bazy danych Eurostatu i EPO, dokumenty urzędowe i / lub legislacyjne, takie jak Europa 2020, literatura naukowa wraz z bezpośredniq obserwacjq, wyszukiwanie $w$ terenie i własne doświadczenia autor. Taki konglomerat zróżnicowanych i multidyscyplinarnych danych może być przetwarzany przez niezliczonq ilość odpowiednio dopasowanych metod, zarówno o charakterze ilościowym, jak i jakościowym, i zdominowany przez holistycznq meta-analizę. Wskaźniki, takie jak GERD, statystyki EPO i DESI, sq porównywalnie wykorzystywane, obserwujqc ewolucje ich czasu w całej UE i wybranych państwach członkowskich UE. Ich wybór wynika $z$ motywacji do reprezentacji i stawienia czoła (domniemanemu) stereotypowi na temat państw członkowskich UE oznaczonych jako "dobre” (DE, FR), „leniwe" PIGS (PT, $I T, G R, S P)$, pozostawiajgc (GB ), w szczególności skandynawskie (DK, FI, SW) i centralne (AT, CZ, PL). To oryginalne badanie odpowiada na wszystkie trzy pytania: (i) próg 3\% nie jest spełniony w większej części UE, (ii) liczba wniosków patentowych i przyznanych patentów rośnie wraz z cyfryzacja, oraz (iii) możliwy zwiqzek między tymi czynnikami i trendami istnieje, ale nie jest rozstrzygajqcy ani drastycznie silny. Generuje to zestaw oryginalnych sugestii, takich jak różnice między państwami członkowskimi UE w zakresie innowacji nie znikajq i mimo że próg 3\% dla strategii Europa 2020 nie zostanie osiqgnięty, liczba opatentowanych wynalazków i praktyczna cyfryzacja mogq nadal rosnqć w całej UE. Konieczne sq dalsze i pogłębione badania, które powinny pomóc UE zmienić podejście do innowacji i sprawić, by była bardziej skuteczna i wydajna.

Słowa kluczowe: DESI, Europa 2020, GERD, innowacje, własność intelektualna, R\&R, badania i rozwój. 


\section{Biographical note}

Radka MacGregor Pelikánová received her Ph.D. in Private Law from the Law School at Charles University in Prague (CZ), LL.M. in Corporate and Finance from Wayne State University in Detroit (USA) and MBA from National American University (USA). She is an academic researcher and lecturer at Metropolitan University Prague. Her research interest is in Intellectual Property Law and its trends; and in current economic, legal and IT business issues. She is the author of almost one hundred academic articles published in several international journals included in WoS and Scopus databases, such as Oeconomia Copernicana, Prace Naukowe Uniwersytetu Ekonomicznego we Wrocławiu, Scientific Papers of the University of Pardubice, Czech Yearbook of International Law - CYIL, Acta Universitatis Agriculturae et Silviculturae Mendelianae Brunensis, Lawyer Quarterly, etc. 